Ambiente \& Água - An Interdisciplinary Journal of Applied Science
ISSN 1980-993X - doi:10.4136/1980-993X
www.ambi-agua.net
E-mail: ambi.agua@gmail.com

\title{
Removal of nutrients due to biomass harvest of Eucalyptus urograndis in different soils: macronutrients
}

\author{
ARTICLES doi:10.4136/ambi-agua.2671
}

Received: 09 Nov. 2020; Accepted: 12 Apr. 2021

\begin{abstract}
Simone Martini Salvador ${ }^{1} \mathbb{D}$; Aline Aparecida Ludvichak ${ }^{1}{ }^{\mathbb{D}}$; Dione Richer Momolli1 ${ }^{1}$; Kristiana Fiorentin dos Santos ${ }^{2 *}$; Catarine Barcellos Consensa ${ }^{1}$ (D); Mauro Valdir Schumacher ${ }^{1}$; James Stahl $^{3}$ iD

\footnotetext{
${ }^{1}$ Departamento de Engenharia Florestal. Universidade Federal de Santa Maria (UFSM), Avenida Roraima, dionemomolli@gmail.com, catarineconsensa@gmail.com, mauro.schumacher@ufsm.br

${ }^{2}$ Departamento de Engenharia Florestal. Universidade Regional de Blumenau (FURB), Rua São Paulo, n 3250, CEP: 89030-000, Blumenau, SC, Brazil.

${ }^{3}$ Klabin S. A., Unidade de Monte Alegre, Avenida Brasil, n 26, CEP: 84275-000, Telêmaco Borba, PR, Brazil. E-mail: jstahl@klabin.com.br

*Corresponding author. E-mail: kristianafiorentin@gmail.com
} n ${ }^{\circ}$ 1000, CEP: 97105-900, Santa Maria, RS, Brazil. E-mail: simone.ufsm@gmail.com, aline_lud@yahoo.com.br,
\end{abstract}

\begin{abstract}
Intensive management of forest stands can increase biomass production, as well as increase the removal of nutrients from the site. This study therefore sought to simulate different harvest intensities and to calculate the nutrient-use efficiency of Eucalyptus urograndis in different types of soil. The study was carried out in a plantation of seven-year-old hybrid E. urograndis in the city of Telêmaco Borba, Paraná, Brazil. The study site included two sub areas with sandy soil and clayey soil (Cambisols Inceptisol and Ferralsols Oxisols, respectively). Using biomass and nutrients stock data, nutrient removal was simulated under five different harvest scenarios. Nutrient-use efficiency was obtained from the relation between the amount of biomass and nutrients of each tree component. Harvesting the whole tree resulted in the removal of approximately $61 \%$ of the nutrients from the site in sandy soil, while in clayey soil $57 \%$ of the nutrients were removed. With harvesting of only the commercial stemwood, only $22 \%$ of the nutrients were removed from the sandy soil, and $21 \%$ from the clayey soil. Stemwood was the component that had the highest nutrient-use efficiency values for all the analyzed nutrients. In conclusion, to achieve nutritional sustainability of E. urograndis stands, the best harvesting system involves the removal of only commercial stemwood. For the production of stemwood, sandy soils have a greater biological efficiency of calcium and magnesium when compared to clayey soil.
\end{abstract}

Keywords: clayey soil, forest nutrition, harvest intensity, nutrient use efficiency, sandy soil.

\section{Remoção de nutrientes pela colheita de biomassa de Eucalyptus urograndis em diferentes tipos solos: macronutrientes}

\section{RESUMO}

O manejo intensivo de povoamentos florestais pode aumentar a produção de biomassa, bem como aumentar a remoção de nutrientes do local. Assim, o objetivo deste estudo foi simular 
diferentes intensidades de colheita e calcular a eficiência de utilização de nutrientes para Eucalyptus urograndis em diferentes tipos de solo. O estudo foi realizado em um plantio do híbrido E. urograndis de sete anos de idade, no município de Telêmaco Borba, Paraná, Brasil. O local de estudo incluiu duas subáreas com solo arenoso e solo argiloso (Cambissolo Háplico e Latossolo Vermelho, respectivamente). Com os dados de estoque de biomassa e nutrientes foi simulada a remoção de nutrientes em cinco cenários de colheita diferentes. A eficiência de utilização de nutrientes foi obtida a partir da relação entre a quantidade de biomassa e os nutrientes de cada componente da árvore. A colheita da árvore inteira resultou na retirada de aproximadamente $61 \%$ dos nutrientes do local em solo arenoso, enquanto em solo argiloso, $57 \%$ dos nutrientes foram removidos. Com a colheita apenas da madeira do fuste comercial, apenas $22 \%$ dos nutrientes foram retirados do solo arenoso e $21 \%$ do solo argiloso. A madeira do caule foi o componente que apresentou os maiores valores da eficiência de utilização de nutrientes para todos os nutrientes analisados. Para alcançar a sustentabilidade nutricional dos povoamentos de E. urograndis, o melhor sistema de colheita envolve a remoção apenas da madeira do tronco comercial. Para a produção de madeira, os solos arenosos apresentam maior eficiência biológica de cálcio e magnésio quando comparados aos solos argilosos.

Palavras-chave: eficiência de utilização de nutrientes, intensidade de colheita, nutrição florestal, solo arenoso, solo argiloso.

\section{INTRODUCTION}

Use of renewable energy was boosted by the oil crisis in the 1970s, increasing the demand for energy biomass, which led to the search for available waste after forest harvesting operations (Egnell, 2017). However, intensively managed forest stands can increase biomass production, but may also increase the removal of nutrients from the site (Viera et al., 2011).

In the case of energetic biomass, the adopted management can involve harvesting all parts of the tree, including the roots, and, in extreme cases, the removal of accumulated litter and understory (Viera et al., 2015). Viera et al., (2013) emphasize that intensively managed plantations with the use of short rotations, without predicting a minimum period required for nutrient replacement, have been found to be the main reason for the chemical exhaustion of soils. However, for long-term forest management, knowledge of the relationships between the amount of nutrients removed by harvests and the bioavailability of nutrients at the site is imperative in order to achieve sustainable energy standards under various rotations (Santana $e t$ al., 2008).

New plantations have been implanted into different types of soils and climatic and management conditions (Kumaraswamy et al., 2015). There are differences between plantations and natural ecosystems, which are self-sustainable. Natural ecosystems are able to maintain their productivity and nutrient dynamics. However, forest plantations are a diversified form of land use, and in order to develop plantations that do not have significant negative impacts on the ecosystem, plantations need to be in harmony with the ecological properties of their environment.

In this context, knowledge about the growth and nutrient allocation to the different biomass components of trees is essential for crop optimization and the nutritional management of plantations (Schumacher et al., 2011; Yan et al., 2017), because the removal of nutrients in the harvest depends on the productivity of the stands and the concentrations of nutrients in the components of biomass (Silva et al., 2013).

The effects of harvesting for forest management are mainly related to the collection system adopted; but other factors, such as climate, soil type, and topography, may also be important (Olsson et al., 2017). The research hypothesis is that the removal of nutrients will occur more 
intensely in the site with sandy soil and this will result in a reduced number of rotations when compared to clayey soil. With the development of new hybrids and genotypes, it is essential to assess their performance under different edaphoclimatic conditions. The region of the present study does not have a historical silvicultural tradition. Considering this aspect, few studies evaluating the removal of nutrients in different scenarios of harvest and soil texture have been published. The objective of this study was to estimate the removal of macronutrients simulating different harvest intensities and to calculate the nutrient-use efficiency of nutrients in hybrid eucalyptus stands on different soil types.

\section{MATERIAL AND METHODS}

\subsection{Characterization of the experimental area}

The study was carried out in stands of seven-year-old hybrid Eucalyptus urograndis (Eucalyptus grandis Hill ex Maiden x Eucalyptus urophylla S.T. Blake) at Farm Monte Alegre in the municipality of Telêmaco Borba, Paraná, Brazil. The climate of the region is characterized as $\mathrm{Cfa}$, according to the climatic classification of Köppen. The average annual temperature is approximately $18.6^{\circ} \mathrm{C}$ and the average annual precipitation reaches $1,443 \mathrm{~mm}$ (Alvares et al., 2013).

Within this study site, subareas with two distinct soil types were chosen. The first subarea had soil with a sandy texture (Cambisols Inceptisols), and the second had soil with a clayey texture (Ferralsols Oxisols). The determination of the physical and chemical attributes of the soil were carried out with the collection of 3 samples in each plot, totaling 12 samples per soil type, in the depths of $0-20 \mathrm{~cm}, 20-40 \mathrm{~cm}$ and $40-60 \mathrm{~cm}$ (Table 1).

In each soil type, four sample plots of $2,550 \mathrm{~m}^{2}$ were plotted, with tree spacing of $3.0 \mathrm{~m} \mathrm{x}$ $2.5 \mathrm{~m}$, composed of 340 plants. The planting was done manually, with a spacing of $3.0 \mathrm{~m} \times 2.5$ $\mathrm{m}$ and an initial density of 1,333 plants per hectare. For the planting, a soil subsoiling was carried out in the planting line, with a depth of $45 \mathrm{~cm}$, where a dosage of $200 \mathrm{~kg} \mathrm{ha}^{-1}$ of natural rock phosphate was incorporated. After the planting, two other fertilizations were carried out; the first was basic fertilization with $15 \mathrm{~kg} \mathrm{ha}^{-1}$ of nitrogen, $35 \mathrm{~kg} \mathrm{ha}^{-1}$ of phosphor, $15 \mathrm{~kg} \mathrm{ha}^{-1}$ of potassium, and the second was cover fertilization with $40 \mathrm{~kg} \mathrm{ha}^{-1}$ of nitrogen, $5 \mathrm{~kg} \mathrm{ha}^{-1}$ of phosphor, $65 \mathrm{~kg} \mathrm{ha}^{-1}$ of potassium $+1,5 \mathrm{~kg} \mathrm{ha}^{-1}$ of boron.

\subsection{Biomass and nutrients}

Based on the diameter at breast-height (DBH) survey of all the trees present in the plots, 12 trees were selected in each plot for the determination of the above-ground biomass (leaves, branches, stembark and stemwood) through the destructive method, thus totaling in each type of soil. The biomass of the roots was analyzed from the selection of four medium DBH trees in each soil type. The root system (stump, fine roots $<2 \mathrm{~mm}$, medium roots of 2.1 to $10 \mathrm{~mm}$, and large roots $>10 \mathrm{~mm}$ ) was extracted using a backhoe and manual excavation (shovels and spades), in an area of $7.5 \mathrm{~m}^{2}$ surrounding the tree (according to spacing) to the depth of $1 \mathrm{~m}$.

In order to evaluate the understory (all naturally occurring vegetation, native or exotic) were collected all the biomass contained within the useful area $\left(7 \mathrm{~m}^{2}\right)$ of each sectioned tree for the sampling of the tree biomass, thus totaling 12 samples in each soil type, from which the average diameter tree minus a standard deviation, the average diameter tree and the average diameter tree plus one were selected. standard deviation. The evaluation of litter on the soil was carried out through the collection of 10 samples in an area of $30 \mathrm{~cm} \times 30 \mathrm{~cm}$ distributed randomly within each plot, totaling 40 samples in each soil type.

The selected trees were sectioned at ground level and divided into the following components: leaves, branches, stembark, stemwood and roots. The amount of green biomass in these components of the tree was determined by means of weighing with a hook scale in the field. 
Table 1. Chemical and physical attributes of distinct soils planted with E. urograndis in the region of Telêmaco Borba, Paraná, Brazil.

\begin{tabular}{|c|c|c|c|c|c|c|}
\hline \multirow{2}{*}{ Attribute } & \multicolumn{3}{|c|}{ Sandy } & \multicolumn{3}{|c|}{ Clayey } \\
\hline & $0-20 \mathrm{~cm}$ & $20-40 \mathrm{~cm}$ & $40-60 \mathrm{~cm}$ & $0-20 \mathrm{~cm}$ & $20-40 \mathrm{~cm}$ & $40-60 \mathrm{~cm}$ \\
\hline Organic matter $(\%)$ & $\begin{array}{c}1.79 \\
(0.14)\end{array}$ & $\begin{array}{c}1.32 \\
(0.22)\end{array}$ & $\begin{array}{c}1.42 \\
(0.43)\end{array}$ & $\begin{array}{c}3.39 \\
(0.12)\end{array}$ & $\begin{array}{c}2.45 \\
(0.15)\end{array}$ & $\begin{array}{c}1.72 \\
(0.05)\end{array}$ \\
\hline $\mathrm{pH}\left(\mathrm{H}_{2} \mathrm{O}\right)$ & $\begin{array}{c}3.97 \\
(0.07)\end{array}$ & $\begin{array}{c}3.97 \\
(0.10)\end{array}$ & $\begin{array}{c}3.95 \\
(0.02)\end{array}$ & $\begin{array}{c}3.98 \\
(0.04)\end{array}$ & $\begin{array}{c}4.19 \\
(0.04)\end{array}$ & $\begin{array}{c}4.41 \\
(0.01)\end{array}$ \\
\hline $\mathrm{P}^{*}\left(\mathrm{mg} \mathrm{dm} \mathrm{dm}^{-3}\right)$ & $\begin{array}{c}1.61 \\
(0.18)\end{array}$ & $\begin{array}{c}1.12 \\
(0.13)\end{array}$ & $\begin{array}{c}0.89 \\
(0.31)\end{array}$ & $\begin{array}{c}0.86 \\
(0.20)\end{array}$ & $\begin{array}{c}0.68 \\
(0.20)\end{array}$ & $\begin{array}{c}0.68 \\
(0.04)\end{array}$ \\
\hline $\mathrm{K}^{*}\left(\mathrm{mg} \mathrm{dm}^{-3}\right)$ & $\begin{array}{c}30.92 \\
(1.48)\end{array}$ & $\begin{array}{l}20.08 \\
(1.73)\end{array}$ & $\begin{array}{l}35.11 \\
(7.71)\end{array}$ & $\begin{array}{l}45.04 \\
(1.16)\end{array}$ & $\begin{array}{l}32.59 \\
(1.28)\end{array}$ & $\begin{array}{l}27.63 \\
(0.26)\end{array}$ \\
\hline $\mathrm{S}\left(\mathrm{mg} \mathrm{dm} \mathrm{m}^{-3}\right)$ & $\begin{array}{c}9.08 \\
(1.58)\end{array}$ & $\begin{array}{l}10.28 \\
(2.04)\end{array}$ & $\begin{array}{l}13.03 \\
(2.02)\end{array}$ & $\begin{array}{l}26.13 \\
(2.33)\end{array}$ & $\begin{array}{l}23.36 \\
(2.41)\end{array}$ & $\begin{array}{l}11.26 \\
(3.90)\end{array}$ \\
\hline $\mathrm{B}\left(\mathrm{mg} \mathrm{dm} \mathrm{m}^{-3}\right)$ & $\begin{array}{c}0.55 \\
(0.03)\end{array}$ & $\begin{array}{c}0.63 \\
(0.06)\end{array}$ & $\begin{array}{c}0.67 \\
(0.05)\end{array}$ & $\begin{array}{c}0.61 \\
(0.07)\end{array}$ & $\begin{array}{c}0.61 \\
(0.08)\end{array}$ & $\begin{array}{c}0.56 \\
(0.08)\end{array}$ \\
\hline $\mathrm{Cu}\left(\mathrm{mg} \mathrm{dm}^{-3}\right)$ & $\begin{array}{c}1.25 \\
(0.27)\end{array}$ & $\begin{array}{c}1.22 \\
(0.29)\end{array}$ & $\begin{array}{c}1.19 \\
(0.23)\end{array}$ & $\begin{array}{c}2.65 \\
(0.14)\end{array}$ & $\begin{array}{c}2.06 \\
(0.20)\end{array}$ & $\begin{array}{c}1.40 \\
(0.09)\end{array}$ \\
\hline $\mathrm{Zn}\left(\mathrm{mg} \mathrm{dm}^{-3}\right)$ & $\begin{array}{c}0.54 \\
(0.07)\end{array}$ & $\begin{array}{c}0.48 \\
(0.11)\end{array}$ & $\begin{array}{c}0.43 \\
(0.09)\end{array}$ & $\begin{array}{c}0.58 \\
(0.12)\end{array}$ & $\begin{array}{c}0.25 \\
(0.01)\end{array}$ & $\begin{array}{c}0.19 \\
(0.02)\end{array}$ \\
\hline $\mathrm{Ca}\left(\mathrm{cmol}_{\mathrm{c}} \mathrm{dm}^{-3}\right)$ & $\begin{array}{c}0.09 \\
(0.02)\end{array}$ & $\begin{array}{c}0.06 \\
(0.01)\end{array}$ & $\begin{array}{c}0.06 \\
(0.01)\end{array}$ & $\begin{array}{c}0.18 \\
(0.05)\end{array}$ & $\begin{array}{c}0.05 \\
(0.01)\end{array}$ & $\begin{array}{c}0.03 \\
(0.01)\end{array}$ \\
\hline $\operatorname{Mg}\left(\mathrm{cmol}_{\mathrm{c}} \mathrm{dm}^{-3}\right)$ & $\begin{array}{c}0.07 \\
(0.01)\end{array}$ & $\begin{array}{c}0.05 \\
(0.01)\end{array}$ & $\begin{array}{c}0.05 \\
(0.01)\end{array}$ & $\begin{array}{c}0.45 \\
(0.06)\end{array}$ & $\begin{array}{c}0.11 \\
(0.02)\end{array}$ & $\begin{array}{c}0.03 \\
(0.01)\end{array}$ \\
\hline $\begin{array}{l}\text { Effective cation exchange capacity } \\
\left(\mathrm{cmol}_{\mathrm{c}} \mathrm{dm}^{-3}\right)\end{array}$ & $\begin{array}{c}2.30 \\
(0.33) \\
\end{array}$ & $\begin{array}{c}2.41 \\
(0.16) \\
\end{array}$ & $\begin{array}{c}2.47 \\
(0.15) \\
\end{array}$ & $\begin{array}{c}3.72 \\
(0.17) \\
\end{array}$ & $\begin{array}{c}2.85 \\
(0.18) \\
\end{array}$ & $\begin{array}{c}2.29 \\
(0.07)\end{array}$ \\
\hline $\begin{array}{l}\text { Saturation per exchangeable base } \\
(\%)\end{array}$ & $\begin{array}{c}2.54 \\
(0.59)\end{array}$ & $\begin{array}{c}1.53 \\
(0.40)\end{array}$ & $\begin{array}{c}2.68 \\
(0.55)\end{array}$ & $\begin{array}{c}2.89 \\
(0.40)\end{array}$ & $\begin{array}{c}1.00 \\
(0.08)\end{array}$ & $\begin{array}{c}0.75 \\
(0.10)\end{array}$ \\
\hline $\begin{array}{l}\text { Exchangeable aluminum } \\
\text { saturation }(\%)\end{array}$ & $\begin{array}{l}89.92 \\
(2.79) \\
\end{array}$ & $\begin{array}{l}96.19 \\
(0.87)\end{array}$ & $\begin{array}{l}93.36 \\
(1.52) \\
\end{array}$ & $\begin{array}{l}80.02 \\
(1.99)\end{array}$ & $\begin{array}{l}91.76 \\
(0.37) \\
\end{array}$ & $\begin{array}{l}94.25 \\
(0.77)\end{array}$ \\
\hline Coarse sand: $2.0-0.2 \mathrm{~mm}(\%)$ & $\begin{array}{l}39.89 \\
(6.41) \\
\end{array}$ & $\begin{array}{l}40.33 \\
(4.07) \\
\end{array}$ & $\begin{array}{l}40.72 \\
(3.88) \\
\end{array}$ & $\begin{array}{l}14.68 \\
(2.77) \\
\end{array}$ & $\begin{array}{l}16.51 \\
(0.59) \\
\end{array}$ & $\begin{array}{l}16.18 \\
(0.97) \\
\end{array}$ \\
\hline Fine sand: $2.0-0.05 \mathrm{~mm}(\%)$ & $\begin{array}{l}40.36 \\
(7.24) \\
\end{array}$ & $\begin{array}{l}40.50 \\
(3.83) \\
\end{array}$ & $\begin{array}{l}37.05 \\
(4.96) \\
\end{array}$ & $\begin{array}{c}6.87 \\
(2.24) \\
\end{array}$ & $\begin{array}{c}5.79 \\
(1.80)\end{array}$ & $\begin{array}{c}6.73 \\
(0.66)\end{array}$ \\
\hline Silt: $0.05-0.002 \mathrm{~mm}(\%)$ & $\begin{array}{c}4.19 \\
(0.27)\end{array}$ & $\begin{array}{c}2.11 \\
(0.63)\end{array}$ & $\begin{array}{c}3.67 \\
(0.81)\end{array}$ & $\begin{array}{l}28.23 \\
(1.94)\end{array}$ & $\begin{array}{l}31.48 \\
(2.78)\end{array}$ & $\begin{array}{l}26.87 \\
(1.09)\end{array}$ \\
\hline Clay: $<0.002 \mathrm{~mm}(\%)$ & $\begin{array}{l}15.56 \\
(1.29)\end{array}$ & $\begin{array}{l}17.06 \\
(1.26)\end{array}$ & $\begin{array}{l}18.56 \\
(1.41)\end{array}$ & $\begin{array}{l}50.22 \\
(1.50)\end{array}$ & $\begin{array}{l}46.22 \\
(1.26)\end{array}$ & $\begin{array}{l}50.22 \\
(0.96)\end{array}$ \\
\hline
\end{tabular}

*Determination of nutrients using the Mehlich ${ }^{-1}$ extractor $\left(\mathrm{HCI}+\mathrm{H}_{2} \mathrm{SO}_{4}\right)$. P: Phosphorus determined by atomic absorption spectrophotometry $(660 \mathrm{~nm})$; K: Potassium determined by flame photometry; S: Sulfur extracted with $\mathrm{Ca}\left(\mathrm{H}_{2} \mathrm{PO}_{4}\right)_{2}$ and determined by turbidimetry $(440 \mathrm{~nm})$; B: Boron extracted with curcumin and determined by spectrophotometry $(460 \mathrm{~nm})$; $\mathrm{Cu}$ : Copper and $\mathrm{Zn}$ : Zinc extracted with HCL $\left(0.1 \mathrm{~mol} \mathrm{~L}^{-1}\right)$ and determined by spectrophotometry atomic absorption $(324.75$ and $213.86 \mathrm{~nm}$, respectively); Ca: Calcium and Mg: Magnesium, extracted with KCL $\left(1.0 \mathrm{~mol} \mathrm{~L}^{-1}\right)$ and determined by spectrophotometry atomic absorption (422.70 and $285.20 \mathrm{~nm}$, respectively); ECEC $=$ Effective Cation Exchange Capacity. Values in parentheses represent the standard errors. 
Representative samples were collected of each component of the biomass of trees, with the exception of stembark and stemwood, which were obtained by 4-cm-thick wooden discs (bark and wood) in the following positions depending on commercial height: base, $25 \%, 50 \%, 75 \%$, $100 \%$ and tree tops, being considered the fraction of $100 \%$ (minimum diameter of $8 \mathrm{~cm}$ ).

After being weighed in the field, the samples were sent to the laboratory to be dried in an air-circulating oven at $70^{\circ} \mathrm{C}$ for 72 hours. Dried samples were subsequently milled in a Wileytype mill, followed by chemical analysis to determine the macronutrients according to Tedesco et al. (1995) and Miyazawa et al. (2009). Sulfuric digestion $\left(\mathrm{H}_{2} \mathrm{SO}_{4}+\mathrm{H}_{2} \mathrm{O}_{2}\right)$ was used for the determination of nitrogen through the Kjeldahl method, nitric-perchloric digestion $\left(\mathrm{HNO}_{3}+\right.$ $\mathrm{HCIO}_{4}$ - [3:1]) for determination $\mathrm{Ca}(422.67 \mathrm{~nm}), \mathrm{Mg}(285.21 \mathrm{~nm})$, with atomic absorption spectrophotometry, K with flame photometry, $\mathrm{P}(660.00 \mathrm{~nm})$ with spectrophotometry and $\mathrm{S}$ (420.00 nm) by turbidimetry.

The total tree biomass per hectare was determined based on the dry weight of each sample multiplied by the total wet biomass of each component of the tree, which was extrapolated based on the number of trees in one hectare. In the case of the understory and litter, the estimate was made by extrapolation of the sample area. For the estimation of the total amount of macronutrient, we computed the product between the nutrient content and the dry biomass for each component. A detailed description of the methodology adopted for biomass determination can also be found in Salvador et al. (2015).

\subsection{Simulation of harvest intensities}

Estimation of nutrient removal was calculated considering the accumulated amount in the biomass and the outputs under five simulations of harvest intensities, with the commercial stemwood being considered with a minimum diameter of $8 \mathrm{~cm}$, as follows:

$1^{\text {st }}$ simulation - Whole tree = harvest of whole biomass tree (stemwood with stembark, tree tops, leaves, branches and roots, leaving understory and litter);

$2^{\text {nd }}$ simulation - Full tree = harvest aboveground biomass (stemwood with stembark, tree tops, leaves and branches, leaving roots, understory and litter);

$3^{\text {rd }}$ simulation - Harvest of the stemwood with stembark and tree tops (leaving leaves, branches, roots, understory and litter);

$4^{\text {th }}$ simulation - Harvest of the commercial stemwood with stembark (leaving tree tops, leaves, branches, roots, understory and litter);

$5^{\text {th }}$ simulation - Harvest of the commercial stemwood (leaving stembark, leaves, branches, tree tops, roots, understory and litter).

\subsection{Potential number of rotations and rate of nutrient removal}

The calculation of the potential number of rotation (PNR) for seven-year-old E. urograndis was performed using the ratio of the amount of nutrients remaining at the site $(\mathrm{kg})$ to the amount of nutrients removed from the site $(\mathrm{kg})$ according to the different harvest intensities for both types of soil (Equation 1).

$$
\text { PNR }=\frac{\left(\text { Amount of nutrient remaining after harvest in } \mathrm{kg} \mathrm{ha}^{-1}\right)}{\left(\text { Amount of nutrient harvested in } \mathrm{kg} \mathrm{ha}^{-1}\right)}
$$

The nutrient removal rate (NRR) was obtained by the ratio between the amount of nutrients $(\mathrm{kg})$ removed with the harvest and the amount of biomass harvested $(\mathrm{Mg})$ for each harvest intensity in the two types of soil (Equation 2).

$$
N R R=\frac{\left(\text { Amount of nutrient harvested in } \mathrm{kg} \mathrm{ha}^{-1}\right)}{\left(\text { Biomass harvested in } M g h a^{-1}\right)}
$$

\subsection{Nutrient-use efficiency}

The nutrient-use efficiency was obtained according to a calculation proposed by Barros 
et al. (1986) using the relation between the amount of biomass and the amount of nutrients of each component, both with the same unit (Equation 3).

$N R R=\frac{\left(\text { Amount of biomass in } M g h a^{-1}\right)}{\left(\text { Amount of nutrient in } M g h a^{-1}\right)}$

\subsection{Statistical analysis}

The data were plotted in box plots for the identification and exclusion of outliers. After, Shapiro-Wilk (to prove the normality of the data) were applied as assumptions to the use of analysis of variance. Results that did not meet the assumptions were transformed by applying the natural logarithm or Box Cox. The amount of nutrients and nutrient-use efficiency were subjected to analysis of variance (ANOVA) for comparison of means, between the same components, in different soil types $(P<0.05)$.

\section{RESULTS AND DISCUSSION}

\subsection{Harvest simulation based on different harvesting intensities}

Quantification of the nutrients in different soil types is essential to be able to establish sustainable harvest systems. Sandy soil had greater amounts of nutrients in the treetop wood when compared to clayey soil, with the exception of calcium and sulfur, which were not significant (Table 2). However, the clayey soil had a higher biomass and amount of nutrients than the sandy soil, except for sulfur. Harvesting tree tops in sandy soils can significantly increase nutrient exports when compared to harvesting this component in clayey soils.

Table 2. Amounts of nutrients available in biomass and soil in stands of seven-year-old E. urograndis in sandy and clayey soils in the region of Telêmaco Borba, Paraná, Brazil.

\begin{tabular}{|c|c|c|c|c|c|c|c|c|}
\hline \multirow{2}{*}{ Solo } & \multirow{2}{*}{ Component } & Biomass & $\mathrm{N}$ & $\mathrm{P}$ & $\mathrm{K}$ & $\mathrm{Ca}$ & $\mathrm{Mg}$ & $\mathrm{S}$ \\
\hline & & $\mathrm{Mg} \mathrm{ha}^{-1}$ & \multicolumn{6}{|c|}{$\mathrm{kg} \mathrm{ha}^{-1}$} \\
\hline \multirow{10}{*}{ Sandy } & Leaves & $2.61^{\mathrm{ns} *}$ & $52.73^{\mathrm{ns}}$ & $2.90^{\mathrm{ns}}$ & $28.15^{\mathrm{ns}}$ & $11.06^{\mathrm{b}}$ & $6.20^{\mathrm{ns}}$ & $2.40^{\mathrm{ns}}$ \\
\hline & Branches & $6.95^{\mathrm{ns}}$ & $19.81^{\mathrm{b}}$ & $1.81^{\mathrm{ns}}$ & $33.65^{\mathrm{ns}}$ & $18.57^{\mathrm{b}}$ & $5.16^{\mathrm{ns}}$ & $2.64^{\mathrm{ns}}$ \\
\hline & Tree tops bark & $1.42^{\mathrm{ns}}$ & $5.99^{\mathrm{ns}}$ & $1.04^{\mathrm{ns}}$ & $8.92^{\mathrm{ns}}$ & $12.06^{\mathrm{a}}$ & $4.12^{\mathrm{ns}}$ & $0.33^{\mathrm{ns}}$ \\
\hline & Tree tops wood & $12.42^{\mathrm{ns}}$ & $27.56^{\mathrm{a}}$ & $2.44^{\mathrm{a}}$ & $42.28^{\mathrm{a}}$ & $6.07^{\mathrm{ns}}$ & $4.89^{\mathrm{a}}$ & $3.84^{\mathrm{ns}}$ \\
\hline & Stembark & $12.07^{\mathrm{ns}}$ & $46.23^{\mathrm{ns}}$ & $6.44^{\mathrm{ns}}$ & $115.19^{\mathrm{ns}}$ & $100.67^{\mathrm{ns}}$ & $28.31^{\mathrm{ns}}$ & $4.84^{\mathrm{ns}}$ \\
\hline & Stemwood & $180.26^{\mathrm{ns}}$ & $186.18^{\mathrm{ns}}$ & $12.02^{\mathrm{ns}}$ & $169.22^{\mathrm{ns}}$ & $87.37^{\mathrm{ns}}$ & $22.44^{\mathrm{ns}}$ & $40.45^{\mathrm{ns}}$ \\
\hline & Roots & $43.05^{\mathrm{ns}}$ & $166.39^{\mathrm{ns}}$ & $7.78^{\mathrm{ns}}$ & $63.57^{b}$ & $57.30^{\mathrm{b}}$ & $24.11^{b}$ & $17.98^{\mathrm{a}}$ \\
\hline & Understore & $1.08^{\mathrm{ns}}$ & $8.17^{\mathrm{ns}}$ & $0.72^{\mathrm{ns}}$ & $10.19^{\mathrm{ns}}$ & $2.61^{\mathrm{ns}}$ & $1.55^{\mathrm{ns}}$ & $0.92^{\mathrm{ns}}$ \\
\hline & Litter & $17.35^{\mathrm{b}}$ & $142.29^{b}$ & $5.59^{\mathrm{b}}$ & $23.09^{b}$ & $96.52^{\mathrm{b}}$ & $28.77^{b}$ & $11.89^{\mathrm{a}}$ \\
\hline & Soil & -- & $222.96^{\mathrm{ns}}$ & $7.24^{\mathrm{ns}}$ & $172.22^{\mathrm{ns}}$ & $84.17^{\text {ns }}$ & $41.34^{\mathrm{ns}}$ & $64.78^{\mathrm{ns}}$ \\
\hline \multirow{10}{*}{ Clayey } & $\mathrm{L}$ & I & 8 & 4.8 & 46 & 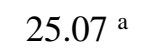 & 11. & $4.18^{\mathrm{ns}}$ \\
\hline & Branches & $11.44^{\mathrm{ns}}$ & $41.35^{\mathrm{a}}$ & $4.05^{\mathrm{ns}}$ & $42.30^{\mathrm{ns}}$ & $98.25^{\mathrm{a}}$ & $12.04^{\mathrm{ns}}$ & $2.87^{\mathrm{ns}}$ \\
\hline & Tree tops bark & $1.28^{\mathrm{ns}}$ & $5.55^{\mathrm{ns}}$ & $1.21^{\mathrm{ns}}$ & $7.35^{\mathrm{ns}}$ & $9.28^{\mathrm{b}}$ & $5.91^{\text {ns }}$ & $0.38^{\mathrm{ns}}$ \\
\hline & Tree tops wood & $12.52^{\mathrm{ns}}$ & $16.86^{b}$ & $1.44^{\mathrm{b}}$ & $19.07^{b}$ & $8.25^{\mathrm{ns}}$ & $2.99^{b}$ & $3.06^{\mathrm{ns}}$ \\
\hline & Stembark & $12.58^{\mathrm{ns}}$ & $46.96^{\mathrm{ns}}$ & $5.98^{\mathrm{ns}}$ & $90.60^{\mathrm{ns}}$ & $157.94^{\mathrm{ns}}$ & $37.61^{\mathrm{ns}}$ & $3.49^{\mathrm{ns}}$ \\
\hline & Stemwood & $211.21^{\mathrm{ns}}$ & $213.66^{\mathrm{ns}}$ & $13.30^{\mathrm{ns}}$ & $218.63^{\mathrm{ns}}$ & $132.86^{\mathrm{ns}}$ & $39.27^{\mathrm{ns}}$ & $52.50^{\mathrm{ns}}$ \\
\hline & Roots & $36.95^{\mathrm{ns}}$ & $137.57^{\mathrm{ns}}$ & $8.64^{\text {ns }}$ & $149.60^{\mathrm{a}}$ & $87.59^{\mathrm{a}}$ & $40.32^{a}$ & $9.63^{b}$ \\
\hline & Understore & $0.65^{\mathrm{ns}}$ & $10.68^{\mathrm{ns}}$ & $0.60^{\mathrm{ns}}$ & $6.37^{\mathrm{ns}}$ & $2.42^{\mathrm{ns}}$ & $1.50^{\mathrm{ns}}$ & $1.48^{\mathrm{ns}}$ \\
\hline & Litter & $20.93^{\mathrm{a}}$ & $169.12^{\mathrm{a}}$ & $6.42^{\mathrm{a}}$ & $29.31^{\mathrm{a}}$ & $165.11^{\mathrm{a}}$ & $41.61^{\mathrm{a}}$ & $9.70^{\mathrm{b}}$ \\
\hline & Soil & -- & $377.89^{\mathrm{ns}}$ & $4.44^{\mathrm{ns}}$ & $210.52^{\mathrm{ns}}$ & $104.21^{\mathrm{ns}}$ & $143.44^{\mathrm{ns}}$ & $121.50^{\mathrm{ns}}$ \\
\hline
\end{tabular}

*Mean of each component in the different soil types followed by ns, did not differ significantly at the level of $5 \%$ error.

Source: Salvador et al. (2019). 
Each element should be analyzed based on the nutrients of the amount in the different components and as amount removed at harvest for reposition. Such importance is evident when observing that the leaves, in spite of presenting low biomass production, have high amounts of nutrients, mainly nitrogen, and the same analysis is valid for calcium in the stembark.

The harvesting only of stem (third simulation), a system adopted by large companies to exploit the stembark and tree tops (wood and bark) as an energy source and stemwood for cellulose production, resulted in the removal of more than $43-50 \%$ of the total phosphor, calcium and potassium in sandy soil. However, in clayey soil, this harvesting system resulted in the removal of 39-43\% of phosphorus, potassium and calcium (Figure 1). Not harvesting the stembark can mitigate the effects of biomass harvest on soil fertility. Corroborating this result, Achat et al. (2015), after studying different biomass harvesting systems, found that harvesting only the stemwood was able to reduce the loss of calcium by $56 \%$. Santos et al. (2020), evaluating the estimation the of nutrient export in different eucalypts genotypes in southern Brazil, observed that the harvesting only the stemwood maintained $\mathrm{Ca}$ in the other biomass components, which varied from 71 to $82 \%$ (E. dunnii and E. benthamii (P1)). In contrast, considering the harvest of the wood with the stem bark, the permanence of the same nutrient in the area reduces to 26 to $37 \%$ (E. benthamii (P2) and E. uro globulus). Therefore, when removing the trunk, debarking of the trees in the stands should be carried out to reduce the export of $\mathrm{Ca}$. In this way, soils with lower concentrations of this nutrient could have their productivity preserved for a longer period (Santos et al., 2019a).
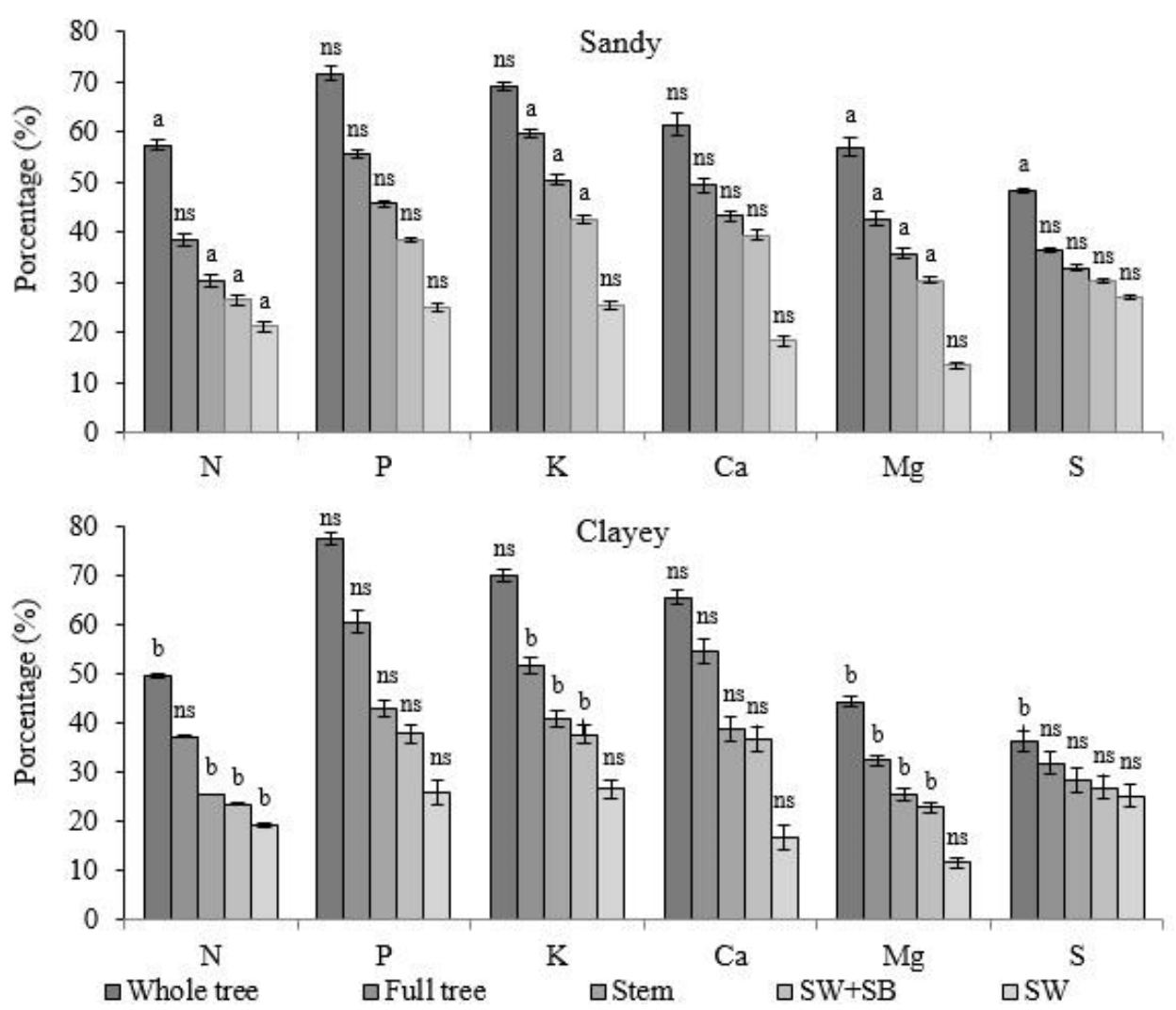

Figure 1. Removal of nutrients at different harvest intensities of seven-year-old E. urograndis in sandy and clayey soils in the region of Telêmaco Borba, Paraná, Brazil.

Whole tree: harvest of whole biomass tree; Full tree: harvest above ground biomass; Stem: harvest of stemwood with stembark; SW+SB: commercial stemwood with stembark; SW: commercial stemwood. "Mean of each harvest's intensities in the different soil types, followed by ${ }^{\mathrm{ns}}$, did not differ significantly at the level of $5 \%$ error. 
Considering the fourth harvesting system $(\mathrm{SW}+\mathrm{SB}$ without tree tops, leaves, branches, roots, understory and litter) in sandy site, nutrient removal reached $43 \%$ for potassium, $39 \%$ for calcium and $38 \%$ for phosphor, resulting in a decrease in nutrient loss of 26, 23 and 34\%, respectively, compared to the first harvesting system. For the clayey soil, this harvesting system resulted in a higher phosphor, potassium and calcium removal $(38 \%, 38 \%$ and $37 \%$, respectively), and a lower removal of magnesium (23\%) (Figure 1).

In a study on nutrient removal rates under different harvesting intensities of the biomass of E. urophylla x E. globulus, Viera et al. (2015) observed that harvesting the stembark resulted in a removal of more than $47 \%$ of the total aboveground accumulated biomass for all macronutrients, with less than $35 \%$ of the stemwood being harvested. As such, it was observed that a biomass harvest of the whole tree resulted in greater removal of nutrients from the site.

In the fifth harvesting system (SW), considering only the removal of commercial stemwood, nutrient exports in the sandy soil would not exceed $27 \%$ for s sulfur and lower than that for the other macronutrients. However, for clayey soil, the maximum nutrient removal was found to be $27 \%$ for potassium and the minimum was found to be $12 \%$ for magnesium (Figure 1).

Under the first harvesting system, 48-72\% and 36-77\% of the nutrients were removed for sandy and clayey soils, respectively. Under the second harvesting system, this was $36-60 \%$ for the sandy soil and $32-61 \%$ for the clayey soil. Under the fifth harvesting system, nutrient removal was limited to $27 \%$ in sandy soils (sulfur) and $27 \%$ (potassium) in clayey soils, on average $39 \%$ and $36 \%$ less than under the first harvesting system, respectively. As such, we recommend using the third harvest system, which includes the only removal of the stemwood, as this is the most sustainable for the site, and will result in the best nutritional conditions for subsequent rotations.

A study by Witschoreck (2008) reported that some of the lost nutrients can be replenished through the application of fertilizers, but the nutrients that can be replenished are usually limited to the triad of elements nitrogen, phosphorus and potassium. Given the distribution of biomass and nutrients in each component of the trees, it is possible to evaluate these during the development of the stand and crop, as this information can be useful for the future maintenance of the site.

In general, for all harvesting systems, the sandy soil presented a higher percentage of removal of nitrogen, potassium and magnesium and sulfur (on average 35\%, 49\%, 36\% and $35 \%$, respectively). The clayey soil has greater phosphorus removal, an average of $49 \%$ among all harvesting systems. This result confirms our hypothesis that sandy soils would present the greatest removal of nutrients by the eucalyptus harvest. Sandy soils naturally present a low capacity for cation exchange, thus presenting the largest stock of nutrients in the eucalyptus biomass in this system. With the harvest, the nutritional impact on this soil is greater than on clay soils.

\subsection{Potential number of rotations and rate of nutrient removal}

Considering an average of all the macronutrients for commercial stemwood harvesting (SW) results in an increase in the number of rotations 5.8 times greater than the whole tree harvest for the sandy soil and 4.8 times for the clayey soil (Table 3). Comparing the number of rotations between SW $+\mathrm{SB}$ and SE, the calcium increases by 2.9 times the number of rotations in the SW for both types of soil (Table 3).

The first harvesting system (whole tree) allows one more rotation only for sulfur, while the clay soil, in this harvesting system, would support another rotation for nitrogen, magnesium and sulfur. Considering only the stemwood harvest (SW), phosphor, potassium and sulfur are the ones that most limit the growth of the next rotations (Table 3).

Rev. Ambient. Água vol. 16 n. 3, e2671 - Taubaté 2021 
Table 3. Estimation of the potential number of rotations based on the amount of nutrients in the biomass and available in the soil, and the nutrient removal rates according to the harvest intensity of $E$. urograndis biomass, at seven years old in sandy and clayey soils in the region of Telêmaco Borba, Paraná, Brazil.

\begin{tabular}{|c|c|c|c|c|c|c|c|c|c|c|c|c|}
\hline \multirow{2}{*}{$\begin{array}{c}\text { Harvest } \\
\text { intensities }\end{array}$} & \multicolumn{6}{|c|}{ Sandy } & \multicolumn{6}{|c|}{ Clayey } \\
\hline & $\mathrm{N}$ & $\mathrm{P}$ & K & $\mathrm{Ca}$ & $\mathrm{Mg}$ & $\mathrm{S}$ & $\mathrm{N}$ & $P$ & K & $\mathrm{Ca}$ & $\mathrm{Mg}$ & $S$ \\
\hline Whole tree & $0.74^{\mathrm{b} *}$ & $0.39^{\mathrm{ns}}$ & $0.45^{\mathrm{ns}}$ & $0.63^{\text {ns }}$ & $0.75^{\mathrm{b}}$ & $1.07^{\mathrm{b}}$ & $1.01^{\mathrm{a}}$ & $0.29^{\mathrm{ns}}$ & $0.43^{\text {ns }}$ & $0.52^{\text {ns }}$ & $1.25^{\mathrm{a}}$ & $1.74^{\mathrm{a}}$ \\
\hline Full tree & $1.59^{\mathrm{ns}}$ & $0.80^{\text {ns }}$ & $0.68^{b}$ & $0.90^{\mathrm{ns}}$ & $1.30^{\mathrm{b}}$ & $1.75^{\mathrm{ns}}$ & $1.68^{\mathrm{ns}}$ & $0.65^{\text {ns }}$ & $0.93^{\mathrm{a}}$ & $0.83^{\text {ns }}$ & $2.08^{\mathrm{a}}$ & $2.14^{\mathrm{ns}}$ \\
\hline Stem & $2.30^{\mathrm{b}}$ & $1.19^{\text {ns }}$ & $0.99^{\mathrm{b}}$ & $1.31^{\mathrm{ns}}$ & $1.79^{\mathrm{b}}$ & $2.03^{\mathrm{ns}}$ & $2.92^{\mathrm{a}}$ & $1.32^{\mathrm{ns}}$ & $1.44^{\mathrm{a}}$ & $1.57^{\mathrm{ns}}$ & $2.91^{\mathrm{a}}$ & $2.51^{\mathrm{ns}}$ \\
\hline $\mathrm{SW}+\mathrm{SB}$ & $2.78^{\mathrm{b}}$ & $1.60^{\mathrm{ns}}$ & $1.34^{\mathrm{b}}$ & $1.53^{\mathrm{ns}}$ & $2.29^{\mathrm{b}}$ & $2.31^{\mathrm{ns}}$ & $3.25^{\mathrm{a}}$ & $1.64^{\mathrm{ns}}$ & $1.65^{\mathrm{a}}$ & $1.72^{\text {ns }}$ & $3.37^{\mathrm{a}}$ & $2.73^{\text {ns }}$ \\
\hline SW & $3.72^{\mathrm{b}}$ & $2.99^{\mathrm{ns}}$ & $2.94^{\mathrm{ns}}$ & $4.45^{\mathrm{ns}}$ & $6.44^{\mathrm{ns}}$ & $2.71^{\mathrm{ns}}$ & $4.19^{\mathrm{a}}$ & $2.83^{\mathrm{ns}}$ & $2.75^{\mathrm{ns}}$ & $4.95^{\mathrm{ns}}$ & $7.55^{\mathrm{ns}}$ & $2.98^{\mathrm{ns}}$ \\
\hline
\end{tabular}

Whole tree: harvest of whole biomass tree. Full tree: harvest above-ground biomass; Stem: harvest of stemwood with stembark; SW+SB: commercial stemwood with stembark; SW: commercial stemwood. "Mean of each harvest intensities, in the different soil types, followed by ${ }^{\text {ns }}$ did not differ significantly at the level of $5 \%$ error.

The results of the present study indicate that harvest intensity planning should be adopted locally, and should be based on the nutrient removal of each tree section harvested and the type of soil, as the clayey soil was suitable for a higher number of rotations of seven-year-old $E$. urograndis, in commercial harvesting systems of the stemwood. Viera et al. (2015) verified that in E. urophylla x E. globulus stands, phosphorus and calcium were the main nutrients to become limiting in subsequent rotations under a harvest system in which the stemwood and stembark were harvested.

Considering the harvest of stemwood only, the limiting nutrients for both soil types were phosphorus, potassium and sulfur, with numbers less than three rotations in this harvesting system. If you consider harvesting stemwood + stembark, the limiting nutrients are phosphorus, potassium and calcium, with less than two rotations. Magnesium is the least limiting growth nutrient, with a potential of six rotations for sandy soil and seven rotations for clay soil.

In the harvest of stemwood + stembark, a very common system by companies in the cellulose sector, the sandy soil has the lowest number of rotations for all the analyzed nutrients. This shows the fragility of this soil and the attention given to fertilizing the plantations implanted in this type of soil to guarantee the sustainability of the system.

Just as the estimated number of rotations varies according to the biomass harvest intensity, the rate of nutrient removal also depends on which components will be harvested (Table 4). The SW harvest system has the lowest nutrient removal rate, as it has the lowest amount of nutrients per biomass.

The lowest rates of nutrient removal were observed with the harvesting of commercial stemwood, independent on the soil type, due to the high amount of biomass and the low amount of nutrients of this component when compared to the others. When comparing the two types of soil, we found that the removal rate is analogous to the harvesting of the commercial stemwood without the stembark, since the harvest of the stembark with tree tops resulted in higher rates of nutrient removal in the clayey soil, which was possibly related to higher biomass production of this soil.

Studies on the removal of nutrients through biomass harvesting provide a basis for the understanding of nutritional dynamics in stands, and are vital for sustainable production, as such studies enable us to predict situations that are critical to both productivity and chemical characteristics of the soil (Viera et al., 2015).

Nitrogen, potassium and calcium are the nutrients that present the greatest reduction in the rate of removal of nutrients according to the harvest intensity for both types of soil. There is a $50 \%$ reduction in the rate of calcium removal if the harvesting system leaves the bark in place and removes only the stemwood. Regardless of the harvesting system, the rate of sulfur removal 
in the clayey soil is practically unchanged, since the largest amount of this element is found in the soil followed by stemwood, a component that is removed in all harvesting systems. As in the sandy soil, the sulfur stock in the soil is lower than in the clayey soil, thus it presents a decrease in the removal rate according to the harvest intensity.

Table 4. Nutrient removal rate based on nutrient and biomass removed, according to harvest intensity of $E$. urograndis biomass at seven years old in sandy and clayey soils in the region of Telêmaco Borba, Paraná, Brazil.

\begin{tabular}{|c|c|c|c|c|c|c|c|c|c|c|c|c|}
\hline \multirow{2}{*}{$\begin{array}{c}\text { Harvest } \\
\text { intensities }\end{array}$} & \multicolumn{6}{|c|}{ Sandy } & \multicolumn{6}{|c|}{ Clayey } \\
\hline & $\mathrm{N}$ & $\mathrm{P}$ & $\mathrm{K}$ & $\mathrm{Ca}$ & $\mathrm{Mg}$ & S & $\mathrm{N}$ & $\mathrm{P}$ & K & $\mathrm{Ca}$ & $\mathrm{Mg}$ & S \\
\hline $\begin{array}{c}\text { Whole } \\
\text { tree }\end{array}$ & $1.96^{\mathrm{ns} *}$ & $0.13^{\text {ns }}$ & $1.79^{\mathrm{b}}$ & $1.14^{\mathrm{b}}$ & $0.37^{\mathrm{b}}$ & $0.28^{\mathrm{ns}}$ & $1.83^{\mathrm{ns}}$ & $0.13^{\mathrm{ns}}$ & $1.91^{\mathrm{a}}$ & $1.72^{\mathrm{a}}$ & $0.50^{\mathrm{a}}$ & $0.25^{\mathrm{ns}}$ \\
\hline Full tree & $1.57^{\mathrm{ns}}$ & $0.12^{\text {ns }}$ & $1.82^{\mathrm{ns}}$ & $1.10^{\mathrm{b}}$ & $0.33^{\mathrm{b}}$ & $0.25^{\mathrm{ns}}$ & $1.56^{\mathrm{ns}}$ & $0.12^{\mathrm{ns}}$ & $1.67^{\mathrm{ns}}$ & $1.63^{\mathrm{a}}$ & $0.41^{\mathrm{a}}$ & $0.25^{\mathrm{ns}}$ \\
\hline Stem & $1.29^{\mathrm{ns}}$ & $0.11^{\mathrm{ns}}$ & $1.63^{\mathrm{ns}}$ & $1.00^{\mathrm{b}}$ & $0.29^{b}$ & $0.24^{\mathrm{ns}}$ & $1.14^{\mathrm{ns}}$ & $0.09^{\text {ns }}$ & $1.35^{\mathrm{ns}}$ & $1.24^{\mathrm{a}}$ & $0.34^{\mathrm{a}}$ & $0.24^{\mathrm{ns}}$ \\
\hline $\mathrm{SW}+\mathrm{SB}$ & $1.21^{\mathrm{ns}}$ & $0.10^{\mathrm{ns}}$ & $1.48^{\mathrm{ns}}$ & $0.98^{\mathrm{b}}$ & $0.26^{\mathrm{b}}$ & $0.24^{\mathrm{ns}}$ & $1.11^{\mathrm{ns}}$ & $0.08^{\mathrm{ns}}$ & $1.32^{\mathrm{ns}}$ & $1.24^{\mathrm{a}}$ & $0.33^{\mathrm{a}}$ & $0.24^{\mathrm{ns}}$ \\
\hline SW & $1.03^{\mathrm{ns}}$ & $0.07^{\mathrm{ns}}$ & $0.94^{\mathrm{ns}}$ & $0.48^{\mathrm{ns}}$ & $0.12^{b}$ & $0.22^{\mathrm{ns}}$ & $1.01^{\mathrm{ns}}$ & $0.06^{\mathrm{ns}}$ & $1.04^{\mathrm{ns}}$ & $0.63^{\mathrm{ns}}$ & $0.19^{\mathrm{a}}$ & $0.25^{\mathrm{ns}}$ \\
\hline
\end{tabular}

Whole tree: harvest of whole biomass tree. Full tree: harvest above ground biomass; Stem: harvest of stemwood with stembark; SW+SB: commercial stemwood with stembark; SW: commercial stemwood. "Mean of each harvest intensities in the different soil types followed by ${ }^{\text {ns }}$ did not differ significantly at the level of $5 \%$ error.

\subsection{Nutrient-use efficiency}

The nutrient-use efficiency (NUE) corresponds to the rate of conversion of nutrients into biomass. This value demonstrates how many units of biomass are formed per unit of nutrient, and the higher the value, the more efficient the conversion of nutrients into biomass. By improving the NUE, stemwood productivity can be increased. The NUE is one of the fundamental parameters for the definition of the best management techniques, and consequently for the maintenance of the productive capacity of forest stands (Santana et al., 2002).

Analyzing the NUE between the different components of the biomass, we found that the stemwood was the component that had the highest values of NUE for all nutrients analyzed, both in sandy and clayey soil, and the inverse was observed in the leaves for nitrogen, phosphorus, potassium, and sulfur. The stembark presented the lowest NUE for calcium, independent of the soil type (Table 5). The high NUE of wood indicates that the xylem used the lowest quantity of nutrients for each unit of biomass produced (Medeiros et al., 2020).

NUE decreased in the following order: phosphorus $>$ magnesium $>$ sulfur $>$ calcium $>$ nitrogen $>$ potassium for sandy and clayey soil. This result is similar to the order found by Santos et al. (2017), for E. urograndis in Rio de Janeiro, Brazil, where the authors observed NUE magnitudes in the order of phosphorus $>$ magnesium $>$ calcium $>$ nitrogen $>$ potassium. However, Schumacher et al. (2019), found inverse values for Eucalyptus spp. in Rio Grande do Sul, Brazil, and reported NUE based on total biomass in the following order: phosphorus > sulfur $>$ magnesium $>$ potassium $>$ nitrogen $>$ calcium.

For the production of all components of the biomass, the elements phosphorus, magnesium and sulfur were the macronutrients most efficiently used in both types of soil analyzed (Table 5). However, considering only the stemwood component of the trees, since this is the component of main commercial interest in the stands, the NUE decreased in the following order: phosphor $>$ magnesium $>$ sulfur $>$ calcium $>$ nitrogen $>$ potassium for sandy and clayey soil. Similar results, although with inversion in the distribution of some nutrients, were reported by Santos et al. (2019b) studying the nutritional efficiency of different eucalyptus genotypes in Southern Brazil $(\mathrm{P}>\mathrm{S}>\mathrm{Mg}>\mathrm{Ca}>\mathrm{N}>\mathrm{K})$.

Rev. Ambient. Água vol. 16 n. 3, e2671 - Taubaté 2021 
Table 5. Nutrient-use efficiency for a plantation of seven-year-old $E$. urograndis on sandy and clayey soils, in the region of Telêmaco Borba, Paraná, Brazil.

\begin{tabular}{|c|c|c|c|c|c|c|c|}
\hline Soil & Component & $\mathrm{N}$ & $\mathrm{P}$ & $\mathrm{K}$ & $\mathrm{Ca}$ & $\mathrm{Mg}$ & S \\
\hline \multirow{7}{*}{ Sandy } & Leaves & $48^{\mathrm{ns} *}$ & $852^{\mathrm{ns}}$ & $88^{\text {ns }}$ & $233^{\mathrm{a}}$ & $407^{\mathrm{a}}$ & $1069^{\mathrm{ns}}$ \\
\hline & Branches & $334^{\mathrm{a}}$ & $298^{\mathrm{ns}}$ & $195^{\mathrm{ns}}$ & $377^{\mathrm{a}}$ & $1045^{\mathrm{a}}$ & $2575^{\mathrm{b}}$ \\
\hline & Tree tops bark & $219^{\mathrm{ns}}$ & $1575^{\mathrm{ns}}$ & $152^{\mathrm{ns}}$ & $109^{\mathrm{b}}$ & $321^{\mathrm{a}}$ & $4136^{\mathrm{ns}}$ \\
\hline & Tree tops wood & $466^{\mathrm{b}}$ & $5180^{\mathrm{b}}$ & $297^{b}$ & $2157^{\mathrm{a}}$ & $2828^{b}$ & $3116^{\mathrm{b}}$ \\
\hline & Stembark & $258^{\mathrm{ns}}$ & $1831^{\mathrm{ns}}$ & $101^{b}$ & $125^{\mathrm{a}}$ & $439^{a}$ & $2462^{\mathrm{b}}$ \\
\hline & Stemwood & $979^{\mathrm{ns}}$ & $14765^{\mathrm{ns}}$ & $1089^{\text {ns }}$ & $221^{\mathrm{a}}$ & $8354^{\mathrm{a}}$ & $4323^{\mathrm{ns}}$ \\
\hline & Roots & $255^{\mathrm{ns}}$ & $5385^{\mathrm{ns}}$ & $671^{\mathrm{a}}$ & $806^{\mathrm{ns}}$ & $1778^{\mathrm{a}}$ & $2374^{\mathrm{b}}$ \\
\hline \multirow{7}{*}{ Clayey } & Lea & $45^{\mathrm{ns}}$ & $834^{\mathrm{ns}}$ & $84^{\mathrm{ns}}$ & $154^{\mathrm{b}}$ & $348^{\mathrm{b}}$ & $951^{\mathrm{ns}}$ \\
\hline & Branches & $227^{\mathrm{b}}$ & $2952^{\mathrm{ns}}$ & $238^{\mathrm{ns}}$ & $12^{b}$ & $575^{b}$ & $3799^{a}$ \\
\hline & Tree tops bark & $235^{\mathrm{ns}}$ & $1321^{\mathrm{ns}}$ & $180^{\mathrm{ns}}$ & $137^{\mathrm{a}}$ & $268^{b}$ & $3713^{\mathrm{ns}}$ \\
\hline & Tree tops wood & $731^{\mathrm{a}}$ & $8885^{\mathrm{a}}$ & $666^{\mathrm{a}}$ & $1966^{\mathrm{b}}$ & $4232^{\mathrm{a}}$ & $4642^{\mathrm{a}}$ \\
\hline & Stembark & $254^{\mathrm{ns}}$ & $2017^{\mathrm{ns}}$ & $133^{\mathrm{a}}$ & $83^{b}$ & $362^{\mathrm{b}}$ & $3464^{\mathrm{a}}$ \\
\hline & Stemwood & $984^{\mathrm{ns}}$ & $16888^{\mathrm{ns}}$ & $1015^{\mathrm{ns}}$ & $1640^{\mathrm{b}}$ & $5851^{b}$ & $4217^{\mathrm{ns}}$ \\
\hline & Roots & $269^{\mathrm{ns}}$ & $4275^{\mathrm{ns}}$ & $247^{b}$ & $437^{\mathrm{ns}}$ & $930^{\mathrm{b}}$ & $3831^{\mathrm{a}}$ \\
\hline
\end{tabular}

"Mean of each component, in the different soil types, followed by ${ }^{\mathrm{ns}}$, did not differ significantly at the level of $5 \%$ error.

The sandy soil has better NUE for calcium and magnesium for the SW harvest system when compared to the clay soil, possibly explained by a luxury consumption, since the clay soil had higher concentrations of these elements in the soil. Considering only the stemwood, the sandy soil showed a higher NUE for calcium and magnesium when compared to clayey soil. The use of fertilization in forest stands is based on the quantification of the nutrients exported from the site by the harvested biomass, and the relation between the biomass production and the nutrients contained in each component (Lafetá et al., 2018). In addition, Santana et al. (2002) point out that nutrient utilization efficiency may be related to the characteristics of each species and to water availability, and nutritional non-equilibrium in the soil-plant system may cause a limitation or excess of one or more available nutrients.

Sandy soil had a higher biological efficiency of calcium and magnesium for the production of stemwood when compared to clayey soil. Magnesium was not a growth-limiting nutrient as observed in the simulation of the number of rotations. However, if the stemwood + stembark harvest is considered, calcium was a limiting nutrient to growth. In sandy soils, E. urograndis showed a higher nutrient-use efficiency than clayey soil for both stemwood and stembark, showing the luxury consumption of the species, since the clay soil had higher concentrations of this element in the soil. This study demonstrated the adaptation of eucalyptus to the different types of soils in Brazil, showing the main limiting nutrients for each type of soil in different harvesting systems. Therefore, the NUE is a parameter of great utility in the selection of species to be used in reforestation, especially in nutrient poor soils (Silva et al., 1983).

\section{CONCLUSIONS}

The best harvesting system considers the removal of only commercial stemwood, as this will reduce the removal of nutrients and result in a better nutritional balance of the sites, independently of the soil type.

Clay soils had a higher biological efficiency of calcium and magnesium for the production of stemwood when compared to clayey soil, possibly explained by a luxury consumption, since the clay soil had higher concentrations of these elements in the soil. 


\section{ACKNOWLEDGEMENTS}

We thank the Klabin Company, and the Monte Alegre farm, for their support during the development of this project, for allowing us to conduct our research in the study area, and for their logistical and financial support. The fourth and fifth authors thank the Coordination for the Improvement of Higher Education Personnel (CAPES) for the scholarship.

\section{REFERENCES}

ACHAT, D. L.; DELEUZE, C.; LANDMANN, G.; POUSSE, N.; RANGER, J.; AUGUSTO L. Quantifying consequences of removing harvesting residues on forest soils and tree growth - A meta-analysis. Forest Ecology and Management, v. 348, n. 15, p. 124-141, 2015. https://doi.org/10.1016/j.foreco.2015.03.042

ALVARES, C. A.; STAPE, J. L.; SENTELHAS, P. C.; GONÇALVES, J. L. M.; SPAROVEK, G. Köppen's climate classification map for Brazil. Meteorologische Zeitschrift, v. 22, n. 6, p. 1-18, 2013. https://doi.org/10.1127/0941-2948/2013/0507

BARROS, N. F.; NOVAIS, R. F.; CARMO, D. N.; NEVES, J. C. L. Classificação nutricional de sítios florestais - descrição de uma metodologia. Revista Árvore, v. 10, p. 112-120, 1986.

EGNELL, G. A review of Nordic trials studying effects of biomass harvest intensity on subsequent forest production. Forest Ecology and Management, v. 383, n. 1, p. 27-36, 2017. https://doi.org/10.1016/j.foreco.2016.09.019

KUMARASWAMY, S.; MENDHAM, D. S.; GROVE, T. S.; O'CONNELL, A. M.; SANKARAN, K. V.; RANCE, S. J. Harvest residue effects on soil organic matter, nutrients and microbial biomass in eucalypt plantations in Kerala, India. Forest Ecology $\begin{array}{lllllll}\text { and Management, } & \text { v. 328, n. 15, p. } 140-149,\end{array}$ https://doi.org/10.1016/j.foreco.2014.05.021

LAFETÁ, B. O.; SANTANA, R. C.; NOGUEIRA, G. S.; NEVES, J. C. L.; PENIDO, T. M. A. Eficiência de utilização de macronutrientes em eucalipto por método não destrutivo estimados por redes neurais artificiais. Ciência Florestal, v. 28, n. 2, p. 613-623, 2018. https://doi.org/10.1016/j.foreco.2014.05.021

MEDEIROS, P. L.; SILVA, G. G. C.; OLIVEIRA, E. M. M.; RIBEIRO, C. O.; SILVA, J. M. S.; PIMENTA, A. S. Efficiency of nutrient use for biomass production of a Eucalyptus clone as a function of planting density in short-rotation cropping. Australian forestry, v. 83, n. 2, p. 66-74, 2020. https://doi.org/10.1080/00049158.2020.1774958

MIYAZAWA, M.; PAVAN, M. A.; MURAOKA, T.; CARMO, C. A. F. S.; MELO, W. J. Análises químicas de tecido vegetal. In: SILVA, F. C. da (ed.). Manual de análises químicas de solos, plantas e fertilizantes. Rio de Janeiro: Embrapa, 2009. p. 190-233.

OLSSON, B. A.; ÂKERBLOM, S.; BISHOP, K.; EKLÖF, K.; RING, E. Does the harvest of logging residues and wood ash application affect the mobilization and bioavailability of trace metals? Forest Ecology and Management, v. 383, n. 1, p. 61-72, 2017. https://doi.org/10.1016/j.foreco.2016.09.017

SALVADOR, S. M.; SCHUMACHER, M. V.; STAHL, J.; SANTOS, J. C. Biomassa arbórea e de subbosque e da serapilheira acumulada em povoamentos de Eucalyptus urophylla $\mathrm{x}$ Eucalyptus grandis. Ecologia e Nutrição Florestal, v. 3, n. 3, p. 82-93, 2015. https://doi.org/10.5902/2316980X19414 
SALVADOR, S. M.; SCHUMACHER, M. V.; STHAL, J.; LUDVICHAK, A. A.; MOMOLLI, D. R.; CONSENSA, C. B. Effects of soil type in nutrient amount in eucalyptus urograndis: Macronutrients. Journal of Experimental Agriculture International, v. 35, n. 3, p. 1-9, 2019. https://doi.org/10.9734/jeai/2019/v35i330204

SANTANA, R. C.; BARROS, N. F.; NEVES, J. C. L. Eficiência de utilização de nutrientes e sustentabilidade da produção em procedências de Eucalyptus grandis e Eucalyptus saligna em sítios florestais do estado de São Paulo. Revista Árvore, v. 26, n. 4, p. 447457, 2002. https://doi.org/10.1590/S0100-67622002000400007

SANTANA, R. C.; BARROS, N. F.; NOVAIS, R. F.; LEITE, H. G.; COMERFORD, N. B. Alocação de nutrientes em plantios de eucalipto no Brasil. Revista Brasileira de Ciência do Solo, v. 32, n. spe, p. 2723-2733, 2008. https://doi.org/10.1590/S010006832008000700016

SANTOS, F. M.; CHAER, M.; DINIZ, A. R.; BALIEIRO, F. C. Nutrient cycling over five years of mixed-species plantations of Eucalyptus and Acacia on a sandy tropical soil. Forest Ecology and Management, v. 384, n. 1, p. 110-121, 2017. https://doi.org/10.1016/j.foreco.2016.10.041

SANTOS, K. F.; LUDVICHAK, A. A.; QUEIROZ, T. B.; SCHUMACHER, M. V.; ARAÚJO, E. F. Biomass production and nutrient content in different Eucalyptus genotypes in Pampa Gaúcho, Brazil. Revista Brasileira de Ciências Agrárias, v. 14, n. 4, e6575, 2019a. https://doi.org/10.5039/agraria.v14i4a6575

SANTOS, K. F.; SCHUMACHER, M. V.; LUDVICHAK, A. A.; ARAÚJO, E. F. Biomass and stock of nutrients in different genotypes of eucalypts in Southern Brazil. Journal of Experimental Agriculture International, v. 34, n. 4, p. 1-12, 2019b. https://doi.org/10.9734/jeai/2019/v34i430178

SANTOS, K. F.; LUDVICHAK, A. A.; QUEIROZ, T. B.; SCHUMACHER, M. V.; ARAÚJO, E. F.; MOMOLLI, D. R. Estimation of nutrient export in eucalyptus genotypes under different harvest intensities in southern Brazil. Idesia, v. 38, n. 1, p. 33-38, 2020. http://dx.doi.org/10.4067/S0718-34292020000100033

SCHUMACHER, M. V.; WITSCHORECK, R.; CALIL, F. N.; LOPES, V. G.; VIERA, M. Produção de biomassa no corte raso em plantio de Araucaria angustifolia (Bertol.) Kuntze de 27 anos de idade em Quedas Do Iguaçu, PR. Ciência Florestal, v. 21, n. 1, p. 53-62, 2011. https://doi.org/10.5902/198050982747

SCHUMACHER, M. V.; WITSCHORECK, R.; CALIL, F. N.; LOPES, V. G. Manejo da biomassa e sustentabilidade nutricional em povoamentos de Eucalyptus spp. em pequenas propriedades rurais. Ciência Florestal, v. 29, n. 1, p. 144-156, 2019. http://dx.doi.org/10.5902/198050985135

SILVA, H. D.; POGGIANI, F.; COELHO, L. C. Eficiência de utilização de nutrientes em cinco espécies de Eucalyptus. Boletim de Pesquisa Florestal, n. 6/7, p.1-8, 1983.

SILVA, P. H. M.; POGGIANI, F.; LIBARDI, P. L.; GONÇALVES, N. A. Fertilizer management of eucalypt plantations on sandy soil in Brazil: Initial growth and nutrient cycling. Forest Ecology and Management, v. 301, n. 1, p. 67-78, 2013. https://doi.org/10.1016/j.foreco.2012.10.033

TEDESCO, M. J.; GINELLO, C.; BISSANI, C. A.; BOHNEN, H.; VOLKWEISS, S. J. Análise de solo, plantas e outros materiais. Porto Alegre: UFRGS, 1995. 174 p. 
VIERA, M.; SCHUMACHER, M. V.; BONACINA, D. M. Biomassa e nutrientes removidos no primeiro desbaste de um povoamento de Pinus taeda L. em Cambará do Sul, RS. Revista Árvore, v. 35, n. 3, p. 371-379, 2011. https://doi.org/10.1590/S010067622011000300001

VIERA, M.; SCHUMACHER, M. V.; KLEINPAUL, I. S. Estoque de nutrientes em consórcios de Eucalyptus urograndis, Acacia mearnsii e Zea mays. Ciência Florestal, v. 23, n. 3, p. 317-327, 2013. https://doi.org/10.5902/1980509810543

VIERA, M.; SCHUMACHER, M. V.; TRÜBY, P.; ARAÚJO, E. F. Implicações nutricionais com base em diferentes intensidades de colheita da biomassa de Eucalyptus urophylla $\mathrm{x}$ Eucalyptus globulus. Ciência Rural, v. 45, n. 3, p. 432-439, 2015. https://doi.org/10.1590/0103-8478cr20120367

WITSCHORECK, R. Biomassa e nutrientes no corte raso de um povoamento de Pinus taeda $L$. de 17 anos de idade no município de Cambará do Sul-RS. 2008. 80f. Dissertação (Mestrado em Engenharia Florestal) - Universidade Federal de Santa Maria, Santa Maria, 2008.

YAN, T.; ZHU, J.; YANG, K.; YU, L.; ZHANG, J. Nutrient removal under different harvesting scenarios for larch plantations in northeast China: Implications for nutrient conservation and management. Forest Ecology and Management, v. 400, n. 15, p. 150-158, 2017. https://doi.org/10.1016/j.foreco.2017.06.004 